\title{
ANALISIS KESULITAN BELAJAR SISWA DALAM PEMBELAJARAN BAHASA INDONESIA SESUAI KURIKULUM 2013 DI SMP SANTO THOMAS 3 MEDAN
}

\author{
Lusiana $^{1}$ Berman Hutahaean ${ }^{2}$ \\ *1 Penulis 1 \\ *2 Penulis 2 \\ Program Studi Pendidikan Bahasa Indonesia, Fakultas Keguruan dan Ilmu Pendidikan, Universitas Katolik Santo \\ Thomas, Jl. Setia Budi No. 479-F Tanjung Sari Medan - Kode Pos No. 20132, email- \\ lusiana@gmail.com,bermanth@gmail.com
}

\begin{abstract}
ABSTRAK
Penelitian ini bertujuan untuk mengetahui Analisis Kesulitan Belajar Siswa dalam Pembelajaran Bahasa Indonesia Sesuai Kurikulum 2013 di SMP St. Thomas 3 Medan. Permasalahan kesulitan belajar dalam kurikulum 2013 (K-13) tersebut dideskripsikan berdasarkan dua aspek yang meliputi faktor kesulitan belajar dilihat dari inteligensi dan faktor kesulitan belajar dilihat dari noninteligensi siswa dalam pembelajaran bahasa Indonesia. Pendekatan penelitian yang digunakan adalah pendekatan kualitatif dengan metode penelitian survei. Populasi dari penelitian ini adalah guru, siswa, orang tua dan peneliti, di SMP St. Thomas 3 Medan yang menerapkan K-13. Data diperoleh melalui angket, wawancara, observasi, dan dokumentasi. Data hasil angket, wawancara, observasi dianalisis menggunakan teknik deskriptif kualitatif. Hasil penelitian menunjukkan bahwa SMP St. Thomas 3 Medan menerapkan K-13 dengan sangat baik. Namun siswa yang belum siap atau tidak mampu untuk menerima kurikulum 2013. Pada aspek pelaksanaan pembelajaran, guru sudah menerapkan beberapa model pembelajaran yang dianjurkan untuk implementasi K-13. Hasil penelitian menunjukkan kesulitan belajar Bahasa Indonesia yang dialami oleh peserta didik di antaranya: kurang lancar membaca, tulisan yang sulit dibaca, keterlambatan dalam pemahaman, malas belajar, serta kurang antusias peserta didik terhadap mata pelajaran bahasa Indonesia. Selain itu guru juga menjadi salah satu penyebab terjadinya kesulitan belajar peserta didik yaitu: cara mengajar guru yang kurang efektif, serta kurangnya motivasi dari keluarga dan orang tua. Melihat dari banyaknya kesulitan belajar yang dialami oleh peserta didik maka sangat diharapkan kepada guru agar lebih dini mendeteksi jenis kesulitan belajar khususnya pada mata pelajaran bahasa Indonesia sehingga dapat dilakukan pencegahan atau pemberian solusi sedini mungkin.
\end{abstract}

Kata kunci: Kesulitan belajar, kurikulum 2013 (K-13), pembelajaran Bahasa Indonesia.

ABSTRACT

This study aims to determine the Analysis of the Students' Learning Difficulties in Learning Indonesian Language according to the 2013 curriculum at SMP Santo Thomas 3 Medan. The problem of learning difficulties in the 2013 curriculum (K-13) is description based on two aspects which include the factors of learning difficulties seen from intelligence and learning difficulties factors seen from the non-intelligence of students in learning Indonesian. The type of this research is qualitative to research methods survey. The populations of this research are the teachers, students, parents and researchers, at Santo Thomas 3 Medan who have applied K-13. Data are obtained through questionnaires, interviews, observation, and documentation. Data from it were analyzed using qualitative descriptive techniques. The result of this research showed that SMP Santo Thomas 3

ISSN 15421-71667

Volume 2 Nomor 2 Desember 2019 
Medan applies K-13 very well. However, students are not ready or unable to accept the 2013 curriculum. In the aspect of implementing learning, the teacher has implemented some learning models for K-13 implementation. The results showed that the difficulties in learning Indonesian language experienced by students included reading fluently. Writing is difficult to read, delays in understanding, lazy to learn, and less enthusiastic about students in Indonesian subjects. In addition, teachers also become one of the causes of learning difficulties of students, namely the teachers who are less effective, and lack of motivation from family and parents. Looking at the number of learning difficulties experienced by students, it is desirable for the teachers to detect earlier types of learning difficulties, especially on Indonesian language subjects so that prevention can be done as soon as possible.

\section{Keywords: Learning Difficulties, 2013 Curriculum (K-13), Indonesian Language Learning}

\section{PENDAHULUAN \\ 1.1 Latar Belakang Masalah}

Dalam pembelajaran kurikulum 2013 masih banyak ditemukan kesulitan belajar siswa. Sugihartono (2007: 149) mendefinisikan kesulitan belajar sebagai suatu gejala yang tampak pada peserta didik yang ditandai dengan adanya hasil belajar yang rendah atau di bawah norma yang telah ditetapkan. Siswa yang mendapat nilai di bawah Kriteria Ketuntasan Minimal (KKM) dapat disebut juga mengalami kesulitan belajar. Kesulitan belajar dapat dilihat dari faktor eksternal dan internal.

Berdasarkan hasil survei yang dilakukan Safni Febri Anzar (2017: 53), di Meulaboh Kabupaten Aceh Barat yang dilaksanakan Maret 2017 dengan jumlah 22 orang siswa, dan ada 16 siswa yang tidak paham ketika guru menyampaikan materi Bahasa Indonesia, Faktor-faktor yang menyebabkan kesulitan belajar Bahasa Indonesia siswa kelas V SD Negeri 20 Meulaboh adalah faktor internal yaitu siswa masih termotivasi dan berminat dalam mengikuti pelajaran Bahasa Indonesia sedangkan faktor eksternalnya adalah guru kurang menggunakan alat peraga dan metode yang digunakan kurang bervariatif dan tidak inovatif. Berdasarkan hasil tersebut di atas maka dapat disimpulkan bahwa siswa kelas V SD Negeri 20 Meulaboh Kecamatan Johan Pahlawan Kabupaten Aceh Barat masih berkesulitan dalam mempelajari pelajaran Bahasa Indonesia.

Selanjutnya, hasil penelitian Ni Putu Listya Dewi Lestari, dkk (2015: 1), bahwa kesulitan-kesulitan belajar bahasa Indonesia siswa kelas IV dalam implementasi kurikulum 2013 di SD Piloting se-Kabupaten Gianyar terdapat $18 \%$ siswa kelas IV di 7 SD piloting se-Kabupaten Gianyar yang mengalami kesulitan dalam pembelajaran bahasa Indonesia pada kurikulum 2013. Kesulitan belajar bahasa Indonesia yang terdiri dari kesulitan membaca dan kesulitan menulis. Terdapat 22\% siswa yang mengalami kesulitan keterampilan membaca di SD Piloting se-Kabupaten Gianyar dan $45 \%$ pada keterampilan menulis. Kesulitan keterampilan membaca terdiri dari beberapa aspek yaitu menceritakan kembali teks yang telah dibaca, menemukan informasi dalam teks melalui kegiatan membaca, menentukan gagasan utama teks, dan membuat kesimpulan dari teks yang telah dibaca.

Hal ini berbanding lurus dengan apa yang dialami oleh siswa di SMP Santo Thomas 3 Medan. Berdasarkan hasil observasi kepada siswa kelas VII terutama siswa kelas VII-2 dan guru-guru khususnya guru bahasa Indonesia, ternyata masih banyak siswa yang mengalami kesulitan dalam belajar berdasarkan kurikulum 2013 tersebut. Para siswa masih kurang mampu untuk mengikuti pembelajaran berdasarkan kurikulum 2013. Pada kurikulum sebelumnya, guru lebih banyak memberikan materi di depan 
kelas, namun pada Kurikulum 2013 siswalah yang dituntut berperan aktif.

Berdasarkan hasil observasi sementara, dan selama peneliti PPL di SMP St. Thomas 3 Medan, peneliti melihat masih ada ketimpangan antar siswa dan guru dalam menerapkan pembelajaran kurikulum 2013 khususnya dalam pembelajaran bahasa Indonesia. Peserta didik masih kesulitan dalam mengikuti pembelajaran kurikulum tersebut. Guru sebagai pengajar harus mampu menerapkan implementasi Kurikulum 2013 namun di lapangan siswa masih sulit menerima pembelajaran sesuai ketentuan yang ada dalam Kurikulum 2013.

Dari hasil wawancara dengan salah satu siswa, peneliti menemukan bahwa siswa sudah terbiasa dengan model pembelajaran yang lama, yakni sudah terbiasa hanya menerima. Kurangnya minat atau rasa ingin tahu siswa terhadap materi, materinya yang terlalu sulit untuk dipahami atau masih sulit untuk menyimpulkan sendiri materi pembelajaran, kurangnya sarana prasarana yang mendukung siswa dalam pembelajaran, dan kesulitan siswa dalam mengakses pembelajaran yang berkaitan dengan materi yang diajarkan. Dari pemaparan siswa tersebut peneliti melihat bahwa siswa masih sulit menerima pembelajaran kurikulum 2013.

Sesuai pernyataan di atas, permasalahan yang muncul adalah cenderung berkaitan dengan masih banyak siswa yang mengalami kesulitan dalam pembelajaran kurikulum 2013 tersebut. Para siswa masih kurang aktif dalam belajar, dan masih terbiasa dengan kurikulum 2006 ataupun KTSP yang cenderung hanya menerima dan guru sebagai pemeran utama dalam pembelajaran.

\section{KAJIAN KEPUSTAKAAN}

\section{Kajian Teori \\ Pengertian Kurikulum dan Kurikulum 2013}

Menurut Undang-Undang Nomor 20 Tahun 2003 tentang sistem Pendidikan Nasional dikatakan bahwa kurikulum adalah seperangkat rencana dan pengaturan mengenai isi dan bahan pelajaran serta cara yang digunakan sebagai pedoman penyelenggaraan kegiatan belajar mengajar.

\section{Tujuan Kurikulum 2013}

Tujuan pendidikan nasional sebagaimana telah dirumuskan dalam undangundang nomor 20 tahun 2003 adalah untuk berkembangnya potensi peserta didik agar menjadi manusia yang beriman dan bertakwa kepada Tuhan yang Maha Esa, berakhlak mulia, sehat, berilmu, cakap, kreatif, mandiri, dan menjadi warga negara yang demokratis serta bertanggung jawab.

\section{Karakteristik Kurikulum 2013}

Menurut Hairun Nufus (2014: 18-19) Kurikulum 2013 adalah kurikulum berbasis kompetensi. Kurikulum berbasis kompetensi adalah outcomes based curriculum dan oleh karena itu pengembangan kurikulum diarahkan pada pencapaian kompetensi yang dirumuskan dari Standar Kompetensi Lulusan. Demikian pula penilaian hasil belajar dan hasil kurikulum diukur dari pencapaian kompetensi. Keberhasilan kurikulum diartikan sebagai pencapaian kompetensi yang dirancang dalam dokumen kurikulum oleh seluruh peserta didik.

Kompetensi untuk Kurikulum 2013 dirancang sebagai berikut:

1. Isi atau konten kurikulum yaitu kompetensi dinyatakan dalam bentuk Kompetensi Inti (KI) kelas dan dirinci lebih lanjut dalam Kompetensi Dasar (KD) mata pelajaran.

2. Kompetensi Inti (KI) merupakan gambaran secara kategori mengenai kompetensi dalam aspek sikap, pengetahuan, dan keterampilan (kognitif dan psikomotor) yang harus dipelajari peserta didik untuk suatu jenjang sekolah, kelas dan mata pelajaran.

3. Kompetensi Dasar (KD) merupakan kompetensi yang dipelajari peserta didik

ISSN 15421-71667

Volume 2 Nomor 2 Desember 2019 
untuk suatu tema untuk SD, dan untuk mata pelajaran di kelas tertentu untuk SMP, SMA, SMK.

4. Kompetensi Inti dan Kompetensi Dasar di jenjang pendidikan dasar diutamakan pada ranah sikap sedangkan pada jenjang pendidikan menengah pada kemampuan intelektual (kemampuan kognitif tinggi).

5. Kompetensi Inti menjadi unsur organisatoris Kompetensi Dasar

6. Kompetensi Dasar yang dikembangkan didasarkan pada prinsip akumulatif, saling memperkuat (reinforced) dan memperkaya (enriched) antara mata pelajaran dan jenjang pendidikan (organisasi horizontal dan vertikal).

7. Silabus dikembangkan sebagai rancangan belajar untuk satu tema (SD) atau satu kelas dan satu mata pelajaran (SMP, SMA, SMK).

8. Rencana pelaksanaan pembelajaran dikembangkan dari setiap KD yang untuk mata pelajaran dan kelas tertentu.

Dapat disimpulkan bahwa pengembangan kurikulum diarahkan pada pencapaian kompetensi yang dirumuskan dari Standar Kompetensi Lulusan dan Keberhasilan kurikulum diartikan sebagai pencapaian kompetensi yang dirancang dalam dokumen kurikulum.

\section{Keunggulan Kurikulum 2013}

Mulyasa (2014: 163-164) berpendapat

bahwa Implementasi Kurikulum 2013 diharapkan dapat menghasilkan insan yang produktif, kreatif, dan inovatif. Hal ini dimungkinkan karena kurikulum ini berbasis karakter dan kompetensi, yang secara konseptual memiliki beberapa keunggulan antara lain sebagai berikut:

1. Bersifat alamiah (kontekstual).

2. Berbasis karakter dan kompetensi boleh jadi mendasar pengembangan kemampuan-kemampuan lain.

3. Ada bidang studi atau mata pelajaran tertentu yang dalam pengembangannya lebih tepat menggunakan pendekatan kompetensi, terutama yang berkaitan dengan keterampilan.

\section{Kelemahan Kurikulum 2013}

Adapun beberapa kekurangan yang terdapat pada kurikulum 2013 adalah sebagai berikut:

Guru banyak salah paham, karena beranggapan dengan kurikulum 2013 guru tidak perlu menjelaskan materi kepada siswa di kelas, padahal banyak mata pelajaran yang harus tetap ada penjelasan dari Guru, Banyak sekali guruguru yang belum siap secara mental dengan kurikulum 2013 ini, Kurangnya pemahaman guru dengan konsep pendekatan Scientific, Kurangnya keterampilan guru merancang RPP, Guru tidak banyak yang menguasai penilaian autentik, Terlalu banyak materi yang dikuasai siswa, Beban belajar siswa dan termasuk guru terlalu berat, sehingga waktu belajar di sekolah terlalu lama.

Pelaksanaan Pembelajaran dalam Kurikulum 2013

Dalam Permendikbud 81 A tahun 2013 dijelaskan bahwa kegiatan pembelajaran merupakan proses pendidikan yang memberikan kesempatan kepada peserta didik untuk mengembangkan potensi mereka menjadi kemampuan yang semakin meningkat dalam sikap, pengetahuan, dan keterampilan yang diperlukan.

1. Kegiatan Pendahuluan

2. Kegiatan Inti: Mengamati, Menanya, Mengumpulkan, Mengasosiasi atau mengolah informasi, Mengkomunikasikan hasil.

3. Kegiatan penutup

\section{Pembelajaran Bahasa Indonesia dalam Kurikulum 2013}

Pembelajaran Bahasa Indonesia yang terdapat dalam kurikulum 2013 dengan pembelajaran berbasis teks bertujuan agar dapat membawa peserta didik sesuai perkembangan mentalnya, dan menyelesaikan masalah kehidupan nyata dengan berpikir kritis. Dalam 
penerapannya, pembelajaran Bahasa Indonesia memiliki prinsip, yaitu sebagai berikut.

a. Bahasa hendaknya dipandang sebagai teks, bukan semata-mata kumpulan kata atau kaidah kebahasaan.

b. Penggunaan bahasa merupakan proses pemilihan bentuk-bentuk kebahasaan untuk mengungkapkan makna.

c. Bahasa bersifat fungsional, artinya penggunaan bahasa yang tidak pernah dapat dipisahkan dari konteks, karena bentuk bahasa yang digunakan mencerminkan ide, sikap, nilai, dan ideologi pemakai/penggunanya.

d. Bahasa merupakan sarana pembentukan berpikir manusia.

\section{Kesulitan Belajar}

Kesulitan belajar merupakan suatu kondisi dimana peserta didik tidak dapat belajar dengan baik, disebabkan karena adanya gangguan, baik berasal dari faktor internal siswa dibatasi faktor inteligensi maupun faktor internal siswa. Faktor-faktor ini menyebabkan siswa tidak mampu berkembang sesuai dengan kepastiannya. Kesulitan belajar ini tidak selalu disebabkan karena faktor inteligensi yang rendah (kelainan mental), akan tetapi dapat juga disebabkan oleh faktor-faktor non inteligensi. Dengan demikian, IQ yang tinggi belum tentu terjamin keberhasilan dalam belajar.

\section{Klasifikasi Kesulitan Belajar}

Secara garis besar kesulitan belajar dapat diklasifikasikan ke dalam dua kelompok, (1) kesulitan belajar yang berhubungan dengan perkembangan (developmental learning disabilities). (2) kesulitan belajar akademik (academic learning disabilities). Kesulitan belajar yang berhubungan dengan perkembangan mencakup gangguan motorik dan persepsi, kesulitan belajar bahasa dan komunikasi, dan kesulitan belajar dalam penyesuaian perilaku sosial.

\section{Penyebab Kesulitan Belajar}

Menurut Abdurrahman (2018: 8) prestasi belajar dipengaruhi oleh dua faktor, internal dan eksternal. Penyebab utama kesulitan belajar (learning disabilities) adalah faktor internal, yaitu kemungkinan adanya disfungsi neurologis; sedang penyebab utama problema belajar (learning problems) adalah faktor eksternal, yaitu antara lain berupa strategi pembelajaran yang keliru, pengelolaan kegiatan pembelajaran yang tidak membangkitkan motivasi belajar anak, dan pemberian ulangan penguatan (reinforcement) yang tidak tepat.

Kesulitan Belajar Secara Umum dan Kesulitan Belajar Secara Khusus Kesulitan Belajar Umum

Anak berkesulitan belajar umum secara nyata mengalami kesulitan dalam tugas-tugas akademik khusus maupun umum, baik disebabkan oleh adanya disfungsi neurologis, proses psikologi dasar maupun sebab-sebab lain sehingga prestasi belajarnya rendah dan anak tersebut berisiko tinggi tinggal kelas.

\section{Kesulitan Belajar Khusus}

Kesulitan belajar khusus dapat dikelompokkan menjadi dua jenis yaitu kesulitan belajar pra-akademik dan kesulitan belajar akademik.

a. Kesulitan Belajar Pra-akademik

1) Gangguan Motorik dan Persepsi

2) Kesulitan Belajar Kognitif

3) Gangguan Perkembangan Bahasa (Disfasia)

4) Kesulitan dalam Penyelesaian Perilaku Sosial

b. Kesulitan Belajar Akademik

1) Kesulitan Belajar Membaca (Disleksia)

2) Kesulitan Belajar Menulis (Disgrafia)

3) Kesulitan Belajar Berhitung (Diskalkulia)

\section{Jenis-jenis Kesulitan Belajar Siswa}

1. Disleksia (dyslexia)

2. Disgrafia (dysgraphia)

3. Diskalkulia (dyscalculia)

4. Kesulitan belajar bahasa dan komunikasi.

5. Kesulitan belajar dalam penyesuaian perilaku sosial. 
6. Gangguan perkembangan motorik dan persepsi.

7. Learning Disabilities UnderachieverSlow Learner.

8. Kesulitan Belajar Umum Anak berkesulitan belajar umum

9. Gangguan Pemusatan Perhatian atau Daya Tangkap Kurang

10. Disleksia

11. Disgrafia

12. Diskalkulia

13. Giftedness Tabel 2.1 Jenis-Jenis Kesulitan Belajar Siswa di Sekolah

Faktor-Faktor Penyebab Kesulitan Siswa dalam Mempelajari Bahasa Indonesia.

Berikut faktor-faktor penyebab kesulitan belajar seperti yang telah dikemukakan oleh Slameto (2005: 57-59)

\section{Faktor Internal}

Faktor internal adalah faktor yang bersumber dari dalam diri individu itu sendiri dalam mencapai tujuan belajar. Faktor internal ini sangat besar pengaruhnya tetapi tidak disadari karena dianggap suatu hal yang biasa, sebenarnya faktor ini dapat dibagi dua bagian yaitu faktor fisiologis dan faktor psikologis.

a. Faktor fisiologis

Faktor fisiologis adalah faktor yang bersumber dari dalam individu yang erat hubungannya dengan masalah kejasmanian terutama tentang fungsi alat-alat panca indra, karena panca indra ini merupakan pintu masuk perangsang dari luar ke dalam individu yang diolah oleh untuk diterima atau tidak pengaruh tersebut.

b. Faktor psikologis

Faktor-faktor psikologis yang mempengaruhi proses belajar siswa antara lain:

1) Kecerdasan (inteligensi)

2) Bakat; yaitu faktor ini ditentukan oleh sifat yang dibawa sejak lahir.

3) Minat
a) Perhatian siswa terhadap pelajaran
b) Rasa senang dalam mengikuti pelajaran

4) Motivasi; yakni Semangat dalam mengikuti pelajaran

5) Cara belajar;

a) Kesiapan mengikuti pelajaran

b) Kesungguhan mengikuti pelajaran

6) Kesehatan;

a) Kondisi fisik (penyakit yang mengganggu, nutrisi)

b) Penglihatan dan pendengaran

\section{Faktor Eksternal}

Faktor eksternal adalah faktor yang berasal dari luar diri siswa yang dapat mempengaruhi prestasi siswa. Faktor eksternal yang dapat mempengaruhi prestasi seseorang ada tiga yaitu faktor keluarga, faktor sekolah, dan faktor masyarakat.

a. Faktor Keluarga
a) Perhatian orang tua
b) Ekonomi keluarga
c) Suasana di rumah

b. Faktor Sekolah

a) Metode mengajar

b) Relasi siswa dengan siswa lain

c) Media pembelajaran

d) Keadaan ruang kelas

e) Waktu pembelajaran

c. faktor Masyarakat

a) Kegiatan siswa di masyarakat

b) Teman bergaul

c) Mass media.

\section{Faktor-Faktor yang Mempengaruhi} Inteligensi

Inteligensi tiap individu cenderung berbeda-beda. Hal ini dikarenakan beberapa faktor yang mempengaruhinya. Adapun faktorfaktor yang mempengaruhi inteligensi antara lain sebagai berikut:

1. Faktor Bawaan atau Keturunan

2. Faktor Minat dan Pembawaan yang Khas

3. Faktor Pembentukan atau Lingkungan

4. Faktor Kematangan.

Kerangka Berpikir

Kesulitan siswa menguasai materi pelajaran merupakan masalah yang perlu dicari penyelesaiannya, sehingga program 
pembelajaran sesuai dengan standar kompetensi yang ditetapkan. Permasalahan yang muncul adalah cara mengetahui dan memperoleh informasi tentang kesulitan belajar siswa. Materi ajar atau bahan ajar bahasa Indonesia secara umum harus disesuaikan pada setiap jenjang pendidikan. Tujuannya agar bahan ajar tersebut sesuai dengan kebutuhan siswa, guru, serta kurikulum yang telah ditentukan (Febriani, 2012).

\section{METODOLOGI PENELITIAN Pendekatan dan Metode Penelitian}

Sesuai rumusan permasalahan dan tujuan penelitian ini, pendekatan penelitian yang digunakan adalah pendekatan kualitatif. Menurut Sugiyono (2018: 9) "Metode penelitian kualitatif adalah metode penelitian yang berlandaskan pada filsafat postpositivisme, digunakan untuk meneliti pada kondisi obyek yang alamiah, (lawan eksperimen) dimana peneliti adalah sebagai instrumen kunci, teknik pengumpulan data dilakukan secara triangulasi (gabungan), analisis data bersifat induktif/kualitatif, dan hasil penelitian kualitatif lebih menekankan makna dari pada generalisasi."

Metode yang digunakan adalah jenis penelitian survei. Penelitian survei adalah penelitian yang dilakukan pada populasi besar atau kecil tetapi data yang dipelajari adalah data dari sampel yang diambil dari populasi. Menurut Prasetiyo (2005: 49) berpendapat bahwa penelitian survei umumnya dilakukan untuk mengambil suatu generalisasi dari pengamatan yang tidak mendalam. Jika sampel yang diambil adalah representatif maka generalisasinya kuat. Maka metode yang digunakan dalam penelitian ini adalah jenis penelitian survei.

Tempat, Kegiatan, dan Waktu Penelitian

Tempat Penelitian

Penelitian ini dilaksanakan di SMP

Santo Thomas 3, J1. Banteng No7 Medan.

Kegiatan dan Waktu Penelitian
Penelitian ini dilakukan pada semester ganjil tahun pembelajaran 2018/2019. Kegiatan dan waktu penelitian dikemas dalam bentuk jadwal berupa tabel seperti yang diuraikan berikut.

Tabel 3.1

Jadwal Kegiatan Penelitian

\begin{tabular}{|c|c|c|c|c|c|c|c|c|}
\hline Kegiatan & $\begin{array}{c}\text { Desem } \\
\text { ber }\end{array}$ & $\begin{array}{c}\text { Janu } \\
\text { ari }\end{array}$ & $\begin{array}{l}\text { Febr } \\
\text { uari }\end{array}$ & $\begin{array}{c}\text { Mare } \\
t\end{array}$ & April & $\begin{array}{c}\mathrm{Me} \\
\mathrm{i}\end{array}$ & $\begin{array}{l}\mathrm{Ju} \\
\mathrm{ni}\end{array}$ & $\begin{array}{l}\text { Ju } \\
\text { li }\end{array}$ \\
\hline $\begin{array}{l}\text { Menyusun } \\
\text { Outline }\end{array}$ & & & & & & & & \\
\hline $\begin{array}{l}\text { Mengumpu } \\
\text { lkan bahan } \\
\text { pustaka }\end{array}$ & & & & & & & & \\
\hline $\begin{array}{l}\text { Penyusunan } \\
\text { proposal }\end{array}$ & & & & & & & & \\
\hline $\begin{array}{l}\text { Seminar } \\
\text { proposal }\end{array}$ & & & & & & & & \\
\hline $\begin{array}{l}\text { Pelaksanaa } \\
\text { n penelitian }\end{array}$ & & & & & & & & \\
\hline $\begin{array}{l}\text { Analisis } \\
\text { data hasil } \\
\text { penelitian }\end{array}$ & & & & & & & & \\
\hline $\begin{array}{l}\text { Penyusunan } \\
\text { skripsi }\end{array}$ & & & & & & & & \\
\hline $\begin{array}{l}\text { Pelaksanaa } \\
\text { n ujian } \\
\text { skripsi dan } \\
\text { revisi }\end{array}$ & & & & & & & & \\
\hline
\end{tabular}

\section{Jenis Data}

Data adalah keterangan yang masih belum diolah menjadi sebuah informasi. Menurut Tersiana, 2018: 67) data adalah hasil pencatatan peneliti baik berupa fakta maupun angka yang dapat dijadikan bahan untuk menyusun suatu informasi. Jenis data yang digunakan adalah deskriptif kualitatif. Deskriptif kualitatif yaitu penelitian yang dilakukan pada kondisi alamiah, dan analisis data yang terkumpul lebih bersifat kualitatif. Peneliti akan mendapatkan data permasalahan yang terjadi dari guru tentang faktor-faktor penyebab kesulitan belajar bahasa Indonesia sesuai kurikulum 2013 di SMP St. Thomas 3 Medan dengan menggunakan bahan observasi, wawancara, dokumen, dan angket.

\section{Sumber Data}

Dalam penelitian ini peneliti menggunakan dua sumber data adalah sebagai berikut:

a. Sumber data primer, adalah analisis permasalahan implementasi kurikulum 2013 dalam pembelajaran bahasa Indonesia di SMP St. Thomas 3 Medan.

b. Sumber data sekunder, yaitu data yang langsung dikumpulkan oleh peneliti sebagai 
penunjang. Data sekundernya adalah tenaga kependidikan dan orangtua siswa.

\section{Teknik Pengambilan Sampel}

\section{Populasi}

Menurut Margono (2017: 118)

"Populasi adalah seluruh data yang menjadi perhatian kita dalam suatu ruang lingkup dan waktu yang kita tentukan”. Dalam hal ini populasi yang dimaksud adalah siswa-siswi SMP St. Thomas 3 Medan yang akan dijadikan sebagai objek/subjek dalam penelitian yang dimaksud.

\section{Teknik Pengambilan Sampel}

Sampel merupakan bagian dari populasi. Menurut Arikunto (2017: 174) menyatakan "sampel adalah sebagian atau wakil yang diteliti". Berdasarkan hasil observasi di sekolah jumlah siswa kelas VII berkisar 127 siswa. Sehingga peneliti mengambil sampel sebagai responden sebanyak 31 orang yaitu siswa kelas VII-2 .

Alat dan Teknik Pengumpulan Data

Alat (instrumen) pengumpulan data yang digunakan dalam penelitian ini adalah observasi, wawancara, dokumentasi dan angket. Alat ini digunakan untuk memperoleh data mengenai masalah yang akan diteliti. Dalam hal ini langkah pertama yang dilakukan adalah meminta persetujuan kepada pihak sekolah untuk mengadakan penelitian. Alat dan teknik pengumpulan data tersebut dijelaskan sebagai berikut.

\section{Observasi}

Menurut Arikunto (2017: 272) "Dalam menggunakan metode observasi cara yang paling efektif adalah melengkapinya dengan format atau blangko pengamatan sebagai instrumen. Format yang disusun berisi itemitem tentang kejadian atau tingkah laku yang digambarkan akan terjadi”.

Adapun observasi yang dilakukan adalah observasi terhadap guru dan siswa.

\section{Wawancara}

Teknik (tahapan) wawancara antara lain sebagai berikut:
1. Menetapkan kepada siapa wawancara itu akan dilakukan

2. Menyiapkan pokok-pokok masalah yang akan menjadi bahan pembicaraan

3. Mengawali atau membuka alur wawancara

4. Melangsungkan alur wawancara

5. Mengkonfirmasikan ikhtisar hasil wawancara dan mengakhirinya

6. Menuliskan hasil wawancara ke dalam catatan lapangan

7. Mengidentifikasi tindak lanjut hasil wawancara yang telah diperoleh.

Bahan wawancara yang digunakan adalah lembar pertanyaan yang berisi tentang jenis-jenis kesulitan belajar siswa yaitu, kesulitan belajar khusus/akademik, perkembangan/pra akademik, faktor endogen dan eksogen, kesulitan belajar umum, dan kesulitan belajar internal.

\section{Dokumentasi}

Dalam penelitian ini, dokumentasi yang akan dilakukan oleh peneliti memiliki beberapa tahapan, antara lain sebagai berikut:

1. Dengan mengumpulkan data melalui sumber tertulis yaitu berupa data sekolah, data identitas guru.

2. Didukung dengan foto-foto kegiatan penelitian.

\section{Angket}

Angket pada penelitian ini terbagi menjadi tiga yaitu angket untuk guru, angket untuk siswa, dan angket untuk orang tua. Bentuk angket yang digunakan dalam penelitian ini adalah angket tertutup. Komponen angket ini meliputi perencanaan, pelaksanaan, penilaian pembelajaran bahasa Indonesia. Uji Instrumen Penelitian

Instrumen penelitian adalah alat bantu yang dipergunakan dalam pengumpulan data (Arikunto 2013: 192). Adapun instrumen yang digunakan dalam penelitian ini adalah data observasi, angket, wawancara, dokumen.

\subsection{Teknik Pengolahan dan Analisis Data}

Teknik pengolahan data dalam penelitian ini menggunakan metode analisis 
interaktif. Model ini ada 4 komponen analisis antara lain sebagai berikut:

1. Pengumpulan Data

2. Reduksi Data

3. Penyajian Data

4. Analisis Data

5. Penarikan Kesimpulan

Prosedur Penelitian

Tahapan analisis kualitatif

Proses pengumpulan data pada analisis data kualitatif dibagi menjadi 4 tahapan, yaitu adalah (Lacey dan Luff dalam Patilima 2013: 95-102)

1. Transkripsi;

2. Pengorganisasian data;

3. Pengenalan;

4. Koding.

\section{Reliabilitas dan Validitas}

Reliabilitas dan validitas merupakan unsur penting dalam semua penelitian termasuk penelitian kualitatif. Untuk menilai reliabilitas dan validitas penelitian kualitatif, berbagai cara dapat dilakukan oleh peneliti, misalnya dengan check list.

\section{Reliabilitas}

Suatu metode yang telah digunakan perlu dijelaskan terutama yang terkait dengan Reliabilitas dari analisis data, yakni:

Gambaran pendekatan dan prosedur analisis data;

a. Memberikan alasan mengapa pendekatan ini digunakan dalam penelitian tersebut;

b. Nyatakan secara jelas proses penyusunan tema, konsep, dan teori dari pengauditan data; dan

c. Tunjukkan fakta-fakta, termasuk penelitian kualitatif dan kuantitatif sebelumnya, pengujian kesimpulan dari analisis yang tepat.

\section{Validitas}

Dalam term validitas dipresentasikan analisis, kemudian cerminan yang diperlukan adalah:

ISSN 15421-71667

Volume 2 Nomor 2 Desember 2019 a. Pengaruh yang kuat dari desain penelitian dan pendekatan analisis pada hasil yang dipresentasikan.

b. Konsistensi temuan, untuk contoh, hasil analisis dapat digunakan oleh lebih dari satu peneliti

c. Hasil yang dipresentasikan luasnya mewakili secara keseluruhan dan berkaitan

d. Menggunakan data asli yang memadai dan sistematik (contoh penggunaan kutipan bukan hanya berasal dari orang yang sama) yang dipresentasikan dari analisis, dengan demikian pembaca yakin bahwa interpretasi data terkait dengan data yang dikumpulkan.

Cara lain menggambarkan Reliabilitas dan Validitas

a. Triangulasi data-data akan dikumpulkan melalui sumber majemuk untuk memasukkan data pengamatan, wawancara, dan diskusi kelompok terfokus;

b. Pemeriksaan anggota-informan akan berperan sebagai pemeriksa sepanjang proses analisis;

c. Pengamatan jangka panjang dan berulang di lokasi penelitian pengamatan tetap dan berulang;

d. Klarifikasi prasangka peneliti;

e. Mempertimbangkan masalah-masalah dari masukan informan;

f. Menyediakan alasan untuk keputusan mereka untuk menyediakan masukan atau tidak;

g. Menjelaskan bagaimana mereka mengetahui tentang masukan, jenis masukan dan mengapa.

\section{Penyajian Data}

Dalam pendekatan kualitatif sangat berbeda dengan pendekatan kuantitatif, terutama dalam menyajikan data. Menurut Matthew B. Miles, psikologi perkembangan dan Michael Huberman ahli pendidikan dari University of Geneva, Switzerland, (Miles dan Huberman, 1992: 15-21) analisis kualitatif, data 
yang muncul berwujud kata-kata dan bukan rangkaian angka. Data itu mungkin telah dikumpulkan dalam aneka macam cara yaitu pengamatan terlibat, wawancara semi terstruktur, dan selanjutnya diproses melalui perekaman, pencatatan, pengetikan, tetapi analisis kualitatif tetap menggunakan kata-kata yang biasanya disusun ke dalam teks yang diperluas.

\section{HASIL PENELITIAN DAN PEMBAHASAN}

\section{Deskripsi Lokasi/Objek Penelitian}

Penelitian ini dilaksanakan di SMP St. Thomas 3 Medan, yang terletak di Jalan Jend. Gatot Subroto Gang Banteng No.7 Medan. Objek dalam penelitian ini adalah guru dan juga siswa kelas VII-2 di SMP St. Thomas 3 Medan dengan jumlah guru Bahasa Indonesia 2 orang, 1 peneliti dan siswa 31 orang.

\section{Deskripsi Data dan Temuan Penelitian Deskripsi Data}

Pengumpulan data dalam penelitian ini berlangsung selama enam hari, terhitung dari hari Senin, tanggal 15 April 2018, pada tanggal 11 April peneliti mengantarkan surat izin penelitian ke sekolah dan karena pada saat itu siswa sedang Ujian Sekolah Berbasis Nasional (USBN) 2019 diberi balasan oleh pihak sekolah pada hari Senin, maka peneliti memulai penelitiannya Pada hari Senin-Jumat (15-19 April 2019). Ada pun data diperoleh dalam penelitian ini merupakan data yang didapatkan dengan berbagai metode pengumpulan data meliputi angket, observasi, wawancara, dan dokumentasi. Deskripsi data masing-masing instrumen secara rinci dilihat dalam penjelasan berikut ini.

\section{Temuan Penelitian}

Sesuai Fokus Penelitian ini yang menjadi pusat penelitian adalah: bagaimana kesulitan belajar siswa dalam pembelajaran bahasa Indonesia sesuai kurikulum 2013 di SMP St. Thomas 3 Medan. Temuan penelitian akan diuraikan satu per satu disesuaikan dengan hasil pengumpulan data melalui instrumen penelitian yang digunakan.

\section{Narasi Hasil Analisis}

Hasil Analisis Kesulitan Belajar Siswa dari Komponen Kesulitan Belajar Khusus/Akademik dan Solusinya

Berdasarkan hasil wawancara dengan Ibu Resdina Simanjuntak dan Ibu Rita Purba selaku guru Bahasa Indonesia di SMP St. Thomas 3 Medan, beliau mengatakan "Di kelas VII Masih banyak siswa yang mengalami kesulitan belajar Bahasa Indonesia berdasarkan kurikulum 2013 baik dalam hal membaca dan juga menulis.

Kesulitan belajar juga disebabkan, karena siswa kelas VII masih terbiasa dengan kurikulum lama dan siswa kelas VII di SMP St. Thomas 3 Medan, masih banyak yang berasal dari SD yang sekolahnya belum menerapkan kurikulum 2013. Sehingga siswa masih belum siap menerima ataupun belum terbiasa dengan kurikulum 2013. "Sebenarnya itu kesulitan kami kalau di sekolah ini, kita sebagai guru sudah berusaha menyetarakan tuntutan kurikulum dengan langkah-langkah atau katakanlah persiapan kami RPP, sarana prasarana, yang kita buat medianya apa? sudah kita buat semenarik mungkin, tapi di sinilah kesulitan kami sering siswa ini sepertinya boleh saya katakan kalau dikatakan 70\% boleh menyerap masih belum, masih mereka terpengaruh dengan kurikulum KTSP", inilah yang dijelaskan oleh Ibu Resdina Simanjuntak. Berdasarkan observasi peneliti ditemukan bahwa siswa mengalami kesulitan belajar bahasa Indonesia. Kesulitan yang sering mereka alami seperti sulit mengemukakan pendapat, menjelaskan, dan masih banyak yang membaca saja belum lancar. Hal ini dapat terjadi karena siswa di SMP St. Thomas 3 Medan terbiasa dengan kurikulum lama, dan juga malas belajar untuk menemukan, mudah menyerah jika sudah dihadapkan dengan masalah. Solusi yang dapat 


\section{Hasil Analisis Kesulitan Belajar Siswa dari Segi Perkembangan/ Pra Akademik dan Solusinya}

Berdasarkan hasil wawancara dengan Ibu Resdina Simanjuntak dan Ibu Rita Purba selaku guru Bahasa Indonesia di SMP St. Thomas 3 Medan, beliau mengatakan "Di kelas VII Masih banyak siswa yang mengalami kesulitan belajar Bahasa Indonesia berdasarkan kurikulum 2013 baik dalam hal kesulitan belajar bahasa dan komunikasi, kesulitan penyesuaian perilaku sosial dan gangguan perkembangan motorik dan persepsi. Dalam hal membaca apalagi kalau di kelas VII, bisa dikatakan mereka masih banyak yang tidak berani tampil di depan kelas untuk mengutarakan pendapatnya.

Kesulitan belajar juga disebabkan, karena siswa kelas VII masih terbiasa dengan kurikulum lama dan siswa kelas VII di SMP St. Thomas 3 Medan, masih banyak yang berasal dari SD yang sekolahnya belum menerapkan kurikulum 2013. Sehingga siswa masih belum siap menerima ataupun belum terbiasa dengan kurikulum 2013. "Sebenarnya itu kesulitan kami kalau di sekolah ini, kita sebagai guru sudah berusaha menyetarakan tuntutan kurikulum dengan langkah-langkah atau katakanlah persiapan kami RPP, sarana prasarana, yang kita buat medianya apa? sudah kita buat semenarik mungkin, tapi di sinilah kesulitan kami sering siswa ini sepertinya boleh saya katakan kalau dikatakan $70 \%$ boleh menyerap masih belum, masih mereka terpengaruh dengan kurikulum KTSP”, inilah yang dijelaskan oleh Ibu Resdina Simanjuntak.

Solusi yang dapat dilakukan adalah dengan memahami kesulitan belajar yang dialami oleh siswa agar guru dapat mengajar dengan memperhatikan kelemahan ataupun kekurangan yang dialami oleh siswa.

\section{Hasil Analisis Kesulitan Belajar Siswa dari Segi Faktor Endogen dan Eksogen dan Solusinya}

Berdasarkan hasil wawancara dengan Ibu Resdina Simanjuntak dan Ibu Rita Purba selaku guru Bahasa Indonesia di SMP St. Thomas 3 Medan, beliau mengatakan "Di kelas VII Masih banyak siswa yang mengalami kesulitan belajar Bahasa Indonesia berdasarkan kurikulum 2013 baik dalam hal ketidakmampuan belajar, kurang berprestasi, dan lambat belajar. Dalam hal membaca apalagi kalau di kelas VII, bisa dikatakan mereka datang dari latar belakang yang berbeda-beda atau SD yang bermacammacam. Jadi begitu banyak siswa yang membaca saja belum lancar. Jadi mau tidak mau guru mencoba mengajarinya secara perlahan. Setelah itu tulisan mereka juga masih banyak yang tidak terbaca. Di sinilah kadang guru menyuruh mereka menulis di halus kasar. Bukan supaya cantik banget tulisannya supaya dia tau perbandingan huruf. Misalnya huruf "a" dengan huruf " $b$ " berapa tingkat perbandingannya, karena bisa saja mereka membuat tingginya sejajar.

\section{SIMPULAN, IMPLIKASI,} KETERBATASAN, DAN SARAN

\section{Simpulan}

Berdasarkan hasil penelitian yang telah dilakukan, maka peneliti menyimpulkan bahwa:

1. Kesulitan belajar Bahasa Indonesia yang dilihat dari Kesulitan belajar Khusus/Akademik. Kesulitan yang dialami siswa adalah kesulitan di bidang belajar membaca dan menulis.

2. Hasil wawancara dengan guru ditemukan siswa mengalami kesulitan dalam pembelajaran bahasa Indonesia. Peneliti menemukan bahwa kesulitan yang mereka alami adalah kesulitan belajar bahasa dan komunikasi, kesulitan penyesuaian perilaku sosial, dan gangguan perkembangan motorik dan persepsi.

3. Kesulitan belajar Bahasa Indonesia yang dilihat dari Kesulitan belajar Faktor endogen . Endogen adalah faktor atau sifat 
yang dibawa oleh individu sejak dalam kandungan hingga kelahiran.

4. Kendala guru dalam mengatasi kesulitan belajar siswa pada pelajaran Bahasa Indonesia yaitu kondisi fisik siswa, sikap siswa dalam belajar, dan psikologis siswa.

5. Guru Bahasa Indonesia di SMP St. Thomas 3 Medan, beliau mengatakan "Di kelas VII Masih banyak siswa yang mengalami kesulitan belajar Bahasa Indonesia berdasarkan kurikulum 2013 baik dalam hal gangguan pemusatan perhatian, apalagi kalau di kelas VII, bisa dikatakan mereka datang dari latar belakang yang berbedabeda atau SD yang bermacam-macam.

\section{Implikasi Hasil Penelitian}

Berdasarkan simpulan hasil penelitian, maka implikasi dari penelitian ini diharapkan dapat dijadikan alternatif pilihan dalam mengembangkan pengetahuan, sumbangan pemikiran, dan masukan positif bagi dunia pendidikan khususnya dalam melaksanakan peran sebagai seorang guru dalam mengatasi kesulitan belajar siswa pada pelajaran bahasa Indonesia.

\section{Keterbatasan Penelitian}

Penelitian ini diterapkan dapat memberi masukan di SMP St. Thomas 3 Medan dalam pembelajaran bahasa Indonesia. Namun demikian, penelitian ini mempunyai keterbatasan sebagai berikut:

1. Masih ada siswa yang tidak mengisi angket yang telah dibagikan dan masih terdapat lembar angket yang kosong.

2. Isi atau bahasa angket masih kurang dipahami oleh siswa.

3. Populasi penelitian ini merupakan SMP ST. Thomas 3 Medan

4. Sedikitnya jumlah sampel yang diambil karena keterbatasan waktu dan biaya peneliti.

\section{Saran}

Berdasarkan kesimpulan maka saran yang dapat disampaikan oleh peneliti sebagai berikut:

ISSN 15421-71667

Volume 2 Nomor 2 Desember 2019

\section{Bagi Guru}

Sebaiknya guru lebih memperhatikan masing-masing siswa dan mengidentifikasi kesulitan belajar yang dialami siswa pada proses pembelajaran dan guru harus dapat menciptakan suasana belajar yang menyenangkan bagi siswa dengan selalu kreatif dan inovatif dalam mengembangkan metode, model pembelajaran yang dipakai dalam kegiatan pembelajaran Bahasa Indonesia.

\section{Bagi Siswa}

Siswa hendaknya memiliki sikap positif pada pelajaran matematika serta lebih aktif dalam pembelajaran. Selain itu siswa hendaknya memperbanyak latihan soal, latihan membaca dan menulis dengan baik dan benar, serta lebih teliti sehingga kesulitan belajar bahasa Indonesia dapat dikurangi.

\section{Bagi Orang Tua}

Hendaknya orang tua senantiasa memperhatikan perkembangan belajar anak khususnya memberi perhatian pada kesulitan belajar Bahasa Indonesia yang dialami. Selain itu orang tua hendaknya menumbuhkan motivasi belajar siswa dan memberikan sugesti positif bahwa Bahasa Indonesia adalah pelajaran yang menyenangkan sehingga siswa mempunyai sikap positif siswa pada pelajaran Bahasa Indonesia.

\section{Bagi Peneliti Lain}

Hasil penelitian ini dapat dikembangkan dengan penelitian yang serupa sehingga dapat ditemukan peran guru lainnya dalam mengatasi kesulitan belajar pada pelajaran Bahasa Indonesia.

\section{DAFTAR KEPUSTAKAAN}

Abidin, 2016. Desain Sistem Pembelajaran dalam Konteks Kurikulum 2013. Bandung: PT Refika Aditama.

Arikunto dan Suharsimi, 2017. Prosedur Penelitian. Jakarta: Renika Cipta.

Agusrida, 2019. Pembelajaran Bahasa Indonesia dalam kurikulum 2013: 
Sebuah Kajian dalam Mata Diklat Penerapan Kurikulum 2013.

Anzar dan Mardhatillah, 2017. Analisis Kesulitan Belajar Siswa pada Pembelajaran Bahasa Indonesia di Kelas V SD Negeri 20 Meulaboh Kabupaten Aceh Barat Tahun Ajaran 2015/2016. Vol. 4 No. 1.

Basuki, dkk. 2017. Kesulitan Belajar Siswa dalam Pembelajaran Bahasa Indonesia. LITERA, Vol. 16, No. 1

Budiman, Aviv. 2015. Implementasi Kurikulum 2013 di SMK Ma'arif Salam.

Delviana, dkk. 2018. Penerapan Kurikulum 2013 Mata Pelajaran Bahasa Indonesia di SMP Negeri 1 Kecamatan Payakumbuh dalam Pembelajaran Teks Cerpen. Jurnal Pendidikan Bahasa Indonesia dan sastra Indonesia. Vol. 1 No. 7.

Hosnan, 2014. Pendekatan Saintifik dan Kontekstual dalam Pembelajaran Abad 21. Bogor: Penerbit Ghalia Indonesia.

Hidayat, 2013. Mengenal Tujuan Pembelajaran Bahasa Indonesia Kurikulum 2013.

Hamid, 2012. Pengembangan Kurikulum Pendidikan. Bandung: CV Pustaka Setia.

Lestari, dkk. 2015. Analisis Kesulitan Belajar Bahasa Indonesia Siswa Kelas IV dalam Implementasi Kurikulum 2013 di SD Piloting Se-Kabupaten Gianyar.

E-journal PGSD Universitas Pendidikan Ganesha. Vol. 3 No. 1.

Margona, S. 2016. Metodologi Penelitian Pendidikan. Jakarta: PT Rineka Cipta.

Mulyasa, 2016. Guru dalam Implementasi Kurikulum 2013. Bandung: PT Remaja Rosdakarya.

Mulyasa, 2016. Pengembangan dan Implementasi Kurikulum 2013. Bandung: PT Remaja Rosdakarya.

Mundofir, 2015. Problematika Pembelajaran Bahasa Indonesia pada Kurikulum
2013 di SMAN 6 dan SMAN 7 Banjarmasin (The Problematic Of Learning Indonesian in Curriculum 2013 In SMA Negeri 7 Banjarmasin). Jurnal Bahasa, Sastra dan Pembelajarannya.

Permendikbud tahun 2016 no 021, Peraturan Menteri Pendidikan dan Kebudayaan Nomor 21 tahun 2016 Tentang Standar Isi Pendidikan Dasar dan Menengah.

Permendikbud Tahun 2016 no 021, Peraturan Menteri Pendidikan dan Kebudayaan Republik Indonesia Nomor 21 Tahun 2016 Tentang Standar Isi Pendidikan Dasar dan Menengah.

Siswanto, dkk. 2014. Pelatihan Kurikulum 2013 Bagi Guru Bahasa Indonesia se Kecamatan Sayung Kabupaten Demak.

Sugiyono, 2018. Metode Penelitian Kuantitatif, Kualitatif, dan $R \& D$. Bandung: Alpabeta.

Yani dan Ruhimat, Teori dan Implementasi Pembelajaran Saintifik Kurikulum 2013. Bandung: PT Renika Aditama.

Yani, 2014. Mindset Kurikulum 2013. Bandung: Penerbit Alfabeta. 